\title{
Research on Application of Situated Cognitive Theory in Mathematics Teaching
}

\author{
Guili Liu \\ Harbin Finance University China Harbin 150040
}

Keywords: Situated teaching; Mathematics; Cognitive theory; Colleges

\begin{abstract}
With the continuous promotion and deepening development of educational system reform in China, experts in mathematics education field begin to explore new teaching methods and measures to promote the deepening development of educational system reform in Chinese universities. Therefore, the research and discussion of situated cognition theory and its role and application in college mathematics curriculum will help to provide theoretical support and reference for the application of situated cognition theory in college mathematics teaching.
\end{abstract}

\section{Introduction}

As an important part of higher education, mathematics has become an important basic subject in higher education because of its comprehensive characteristics, high applicability and difficult learning. The cognitive theory of the situation as an effective teaching method in higher mathematics teaching, teachers in the teaching process pay attention to the dominant position of students, and teachers in the teaching process of mastering the cognitive theory of the situation for improving the quality of teaching and the teaching effect has important role. Therefore, it is of great significance to discuss the application of situated cognitive theory to the teaching of mathematics, which is of great significance to the improvement of the teaching effect of higher mathematics.

\section{The Connotation of Situated Cognition Theory}

The situation or environment are collectively referred to as "situation", the general definition from two aspects: firstly, considering the distinction from the angle of sociology, situation is a reaction made in a particular environment, and it is established on the basis of social and individual. Secondly, from the point of view of education, learning situation is refers to the student's learning environment which is based on the student and learning atmosphere. The study found that only teaching content will be placed in the real teaching situation, teaching will have vitality that is the true meaning of teaching, and the cognitive theory of the situation that the transmission of knowledge and learning is a dynamic process which is composed of every organization and teaching subject contact.

\section{The Role and Significance of Situated Cognition Theory in Mathematics Teaching}

The study found that, with the deepening of educational system reform in our country in recent years, situated cognition theory has been widely used in mathematics teaching in Colleges and universities, and the teaching effect has been recognized by teachers and students, the mathematical theory of situated cognition in mathematics teaching in all aspects put forward analysis and solve all the play a great role, and its function is mainly manifested in the following aspects:

The mathematics teaching content is boring, boring and leads to many students in mathematics learning is not interested, even tired, and the cognitive theory of the situation is mainly carried out according to the actual teaching content whose advantage is to develop appropriate teaching environment for students according to the actual content of teaching, so that students are interested in learning mathematics, and improving attention and the efficiency of learning in the classroom, so as to realize the purpose of improving the students' mathematics achievement.

The implementation of situated cognition theory in college mathematics teaching can change 
students' boring learning background and learning environment to stimulate students' enthusiasm for comprehensive learning and promote students' autonomous learning ability. Moreover, because situated cognition theory can improve students' learning ability and improve their learning ability and problem-solving ability in many ways, and its promotion in college mathematics teaching is of positive significance.

Situated cognition theory can guide effective communication between students and teachers, and help students develop their own learning ability and coordination ability. Mathematics as a way to solve problems, and mathematics problems are generally derived from reality. Therefore, when carrying out mathematics teaching, teachers should actively introduce situated teaching mode to stimulate students' learning enthusiasm, and promote communication between students.

\section{The Application Strategy of Situated Cognition Theory in Mathematics Teaching}

Due to the important role of situated cognition theory in higher mathematics teaching and its positive significance for improving the teaching effect of Higher Mathematics in China, it is necessary to discuss its application problems. Therefore, in the actual teaching process, taking students as the teaching subject, teachers as a guide, according to the teaching content and teaching mode, application strategy adopted the theory of cognitive context is scientific and reasonable in order to enhance the promotion and application of the theory of situated cognition in mathematics teaching.

\section{Teaching Objectives Under the Situated Cognition Theory}

There are many mathematical knowledge points and contents in mathematics teaching that are abstract. Students are very difficult to learn and difficult to understand and apply. At this time, teachers should adopt corresponding strategies to teach. First of all, before the lecture, the teacher should proceed according to the teaching contents and its characteristics, design the classroom and make reasonable adjustment according to the curriculum objectives, and strive to achieve the abstract problem specific to stimulate students' enthusiasm for learning at the same time, improve the students' learning effect. Such as: teachers in teaching, according to the teaching contents of the introduction of the appropriate number of stories, video, audio or video, to arouse their interest in learning, and to ease the students in accepting new knowledge, and the introduction of the situation as a prelude to a story can effectively promote students' learning passion and classroom teaching atmosphere to a climax.

\section{Problems in the of Situated Cognition Theory}

In the teaching of mathematics, the question is not only the expansion of the content of mathematics, but also the guidance and promotion of the teachers' ideas on the students. So it is the teaching of higher mathematics, in order to better reflect the focus of teaching, the teachers in the classroom generally use the way of refining the content of class learning, and focus on students' learning direction and guidance, through the way of questioning, students' learning enthusiasm has been fully mobilized. In the course of teaching, the situated cognitive theory put forwards the problem, the general should be carried out according to the following steps: (1) teachers in teaching should be read carefully before the teaching content, the teaching contents are analyzed and discussed according to the characteristics, and then extracted the problem; (2) teachers in the teaching process, and students should be arranged reasonably the discussion, in order to ensure the students through independent discussion, get the answer to the question; (3) teachers should in the teaching process and students in the discussion process, to effectively guide students through the teaching method which can effectively improve the students' autonomous learning ability and thinking ability. For example, in higher mathematics, when students learn the structure and shape of objects, teachers should set up corresponding situations, and then analyze and discuss teaching contents according to circumstances, so as to find out the factors that decide the shape of objects and finally finish teaching.

\section{Solving Problem Under the Situated Cognition Theory}

Because of the great difficulty of higher mathematics curriculum, students often lose interest in learning because of their boring and difficult contents. It is found that teachers can effectively solve 
students' problems in mathematics learning process by using the theory of situated cognition, and also effectively solve the problem of teachers' teaching efficiency in the new curriculum reform. However, due to the fact that the main body of situated cognition theory is students, it is an important link in current mathematics teaching to train students' learning ability according to the actual situation of students and the corresponding teaching contents, and the specific implementation steps are as follows:

In the design of mathematics teaching situation, students must be taken as the main body, and the teachers should guide the students rationally around the teaching content.

In the process of teaching, teachers should not only cultivate students' ability of independent learning and problem-solving, but also cultivate students' creativity in the process of teaching.

\section{Strengthening the Interaction Between Teachers and Students}

Because situated cognition teaching emphasizes interaction in teaching process, in the process of teaching, increasing interaction and cooperation between teachers and students can effectively achieve teaching objectives. When carrying out education and teaching activities, teachers should design corresponding scenes and characters according to the contents and characteristics of mathematics teaching, then let students enter into the settings and the middle area of the characters, so as to promote students' exploration of situations. For example, the teachers in the process of carrying out the teaching of probability should carry out some activities related to interactive teaching, the specific steps are as follows: firstly, teachers can design a link draw to carry out the teaching activities with the big wheel and the corresponding gift, through the activities held, and students can deepen the probability problem understanding and cognition; secondly, teachers in classroom activities, teachers should grasp the degree of activity, which can not deviate from the main body of teaching to ensure that students actively carry out classroom teaching activities at the same time to complete the learning process; finally, to carry out the teaching activities, teachers should strengthen their own with the students. Communication and exchange which can not only actively mobilize students' learning enthusiasm and passion, but also help teachers based on students' learning. The situation is effectively guided to close the distance between the students and the teachers, thus promoting the improvement of the teaching efficiency.

\section{Situation Assisted Instruction}

In mathematics teaching, teachers should be based on the corresponding teaching contents and chapters designed mathematics learning to promote students to achieve the sublimation of thinking and learning ability in the specific situation, and also can achieve the purpose of education and teaching activities, the specific implementation steps are as follows: The scene more can promote the students into mathematics learning, and improve students' learning ability. Therefore, teachers in the teaching content according to the situation when the design that must be designed according to the actual situation and the teaching content to avoid some practical design out of teaching situation; In order to improve the teaching effect, teachers should be based on the students' learning ability and the basic situation, grouping students in the classroom and then in the teaching, the teachers guide students to actively discuss and exchange; In the context of teaching, teachers should establish the student-centered, teacher assisted teaching mode, and pay attention to each student's learning situation and act in the teaching process to give students enough incentive.

\section{Strengthening the Flexible Teaching Methods}

With China's education system reform, the original unified teaching mode is not suitable for the situation of contemporary education development, teaching activities are carried out using situated cognitive teaching, we must focus on the teaching methods of flexible, specific steps are as follows: Teachers should be based on the introduction of the teaching content, teaching situation, teaching content abstract the specific, and thus enhance the teaching effect and learning enthusiasm of students; About teachers in teaching activities, we must carry out flexible teaching content, actively introduce the situation to promote the upgrading of teaching. 


\section{Conclusion}

In summary, the situated cognitive theory is the ion, because it can effectively improve the students' enthusiasm for learning and teaching effect and is widely used in the mathematics teaching in Colleges and universities, and to realize the effective application of situated cognition theory in mathematics teaching, teachers should establish the correct teaching idea, understand the characteristics of the situated cognition and teaching according to the teaching content of active teaching design the situation in order to improve mathematics teaching effect.

\section{Reference}

[1] Zhixin Cui. The application of situated cognition theory in Higher Vocational Mathematics Teaching[J].Heilongjiang Science, 2015(7):124.

[2] Zhengju Hu. The application of Situated cognition theory in Higher Vocational Mathematics Teaching[J].Mathematics Learning and Research, 2014(19):17.

[3] Xin Sui. The cultivation of mathematical modeling thinking ability in Higher Vocational Mathematics Teaching[J].Examination Weekly, 2015(91):61. 